\title{
ANALYSIS OF STUDENTS' MATHEMATICAL COMMUNICATION OF JUNIOR HIGH SCHOOL (SMP) THROUGH THE SAVI (SOMATIC, AUDITORY, VISUALIZATION, INTELLECTUALLY) APPROACH
}

\author{
Mazidah Maghfiroh, Baiduri, Siti Khoiruli Ummah \\ Study Program of Mathematics Education, Faculty of Teacher Training and Education \\ University of Muhammadiyah Malang \\ mazidahmaghfiroh@gmail.com
}

\begin{abstract}
The purpose of this research is to analyze the students' mathematical communication in junior high school verbally as well as written by means the approach of SAVI. This research uses qualitative approach with descriptive research type. The subjects of this study totally 31 students of junior high school on a class VIII, while the object is the students' mathematical communication, verbal as well as written using the approach of SAVI. The instrument used in this study are observation and test sheets. The data will be analyzed using three plots, namely: data reduction, data presentations and summarizing. The result of this study shows that students' verbal communication in mathematics by means the approach of SAVI is in good category. Students can finely declare the examples, explain mathematics representations, give questions and answers, declare the situation of a problem in mathematical model, discuss a problem, conclude the result of the discussion and make summary related to the subject. The written mathematical communication of students is also in good category. Students can do well in writing mathematical ideas and representations, finding important points, rewriting the test in mathematical model, finishing the problem and wraiting the summary related to the subject.
\end{abstract}

Keywords: mathematical communication, the approach of SAVI.

\section{INTRODUCTION}

A graduate qualification profile is required to achieve national education objectives as set forth in the competency standards of graduates. According to the Regulation of the Minister of Education and Culture Number 20 of 2016 on Competency Standards of Graduates of Primary and Secondary Education Section 1 Paragraph 3, the competency standards of graduates are the criteria of graduate qualification which includes attitudes, knowledges and skills aimed at the main reference of the development of content standards, process standards, educational assessment standards, educator standards and education personnel, equipment and infrastructure 
standards, management standards and financing standards. Process standards according to the Regulation of the Minister of Education and Culture Number 22 of 2016 on Standard Processes of Primary and Secondary Education Section 1 Paragraph 1 is a criterion on the implementation of learning in educational units to achieve graduate competence. The standards of this process include the planning of the learning process, the implementation of the learning process, the assessment of learning outcomes, and the supervision of the learning process. Content standard according to the Regulation of the Minister of Education and Culture Number 21 of 2016 on Basic and Secondary Education Content Standards Section 1 Paragraph 1 and Paragraph 2 comprise the level of competence and core competence according to the level and type of education. Core competencies include spiritual attitudes, social attitudes, knowledge and skills. Thus, process standards and content standards are the standards for achieving graduate competency standards in realizing national education objectives.

Communication is an important aspect of learning. Communication is an essential part of mathematics and mathematics education (Turmudi, 2008). According to the Regulation of the Minister of Education and Culture Number 21 of 2016 on Basic and Secondary Education Content Standards Section 1 Paragraph 9, that demonstrate the skills of reasoning, processing, and communicating is one of the competencies to be achieved in the core competence of skills. According to the National Council of Teachers of Mathematics (2000), communication is one of the standard learning process. This means showing the skills of reasoning, processing, and communicating is one of the core competencies of the skills and learning process standards.

Approach is an important aspect of learning. The selection of the right approach in learning can make the learning process run smoothly and more efficiently. SAVI (Somatic, Auditory, Visualization, Intellectually) is one of the alternative approaches that can be applied in learning. The SAVI (Somatic, Auditory, Visualization, Intellectually) approach which is part of the Accelerated Learning concept is a fast and natural way of learning which is a modern movement that breaks the way of learning in structured education and training (Hamid, 2011). This approach meets the standard of learning process according to Regulation of the Minister of Education and Culture Number 22 of 2016 on Standard Process of Primary and Secondary Education Section 1 Paragraph 2 because it is a scientific approach. 
Communication and SAVI (Somatic, Auditory, Visualization, Intellectually) approach in learning is very important. There are two important reasons why communication in mathematics learning needs to be nurtured in school, first is mathematics not just a thinking tool, a tool for finding patterns, solving problems or making decisions but also as a tool for communicating ideas clearly, precisely and concisely; The second is as a social activity in learning mathematics in schools, mathematics is also a vehicle for interaction between students and also as a means of communication of teachers and students (Baroody in Ansari, 2009). The results of observations and interviews to teachers of class VIII-B SMP Negeri Malang, teachers convey that at the time of teaching and learning activities are still dominated by teachers. This can be seen when teachers explain the students tend to be silent, less daring to ask and give opinions, students prefer engrossed with other activities rather than listening to teacher explanations, as well as students' communication, most of the students still have difficulty in communicating lessons when presentations, ask questions or answer questions verbally as well as written. Some research results indicate that students' mathematical communication ability is not as expected.

This is as shown by previous research which has the conclusion that students' mathematical communication ability is still low, either in verbal communication or writing (Istiqomah, 2007). Other research also shows that the improvement of mathematical communication ability of students who gain learning with the application of Quantum Learning approach is better than students who get conventional learning and student motivation in the class that get learning with Quantum Learning approach is better than the motivation of students who learn conventionally (Darkasyi, Et al; 2014). Furthermore, other studies also suggest that students' mathematical communication skills in their learning using Think-Talk-Write (TTW) learning are significantly better than those in the conventional way at the 5\% significance level (Elidia, 2012). Furthermore, other studies have also shown that the mathematical analogy of students acquiring learning with the Wingeom-based SAVI (Somatic, Auditory, Visualization, Intellectually) approach is better than that of students receiving conventional learning (Putra, 2011). Other studies also show that the application of SAVI approach (Somatic, Auditory, Visualization, Intellectually) can improve student learning outcomes (Mayliana, 2013). 
Based on the description of the importance of mathematical communication, SAVI approach (Somatic, Auditory, Visualization, Intellectually) and the observation of mathematics learning in school, research on mathematical communication through SAVI (Somatic, Auditory, Visualization, Intellectually) approach needs to be done. The aim of this research is to describe the students' mathematical communication verbally as well as written by means the approach of SAVI (Somatic, Auditory, Visualization, Intellectually).

\section{METHODS}

The approach in this research is qualitative approach. A qualitative approach is an approach that focuses more on the aspects of the process than the outcome. Researchers observe directly about students' communication verbally as well as written by means the approach of SAVI (Somatic, Auditory, Visualization, Intellectually) during the learning process. The type of research used is descriptive research because this study aims to describe students' mathematical communication verbally as well as written by means the approach of SAVI (Somatic, Auditory, Visualization, Intellectually).

This research was conducted in SMP Negeri 22 Malang City which is located at Street El Tari Villa Gunung Buring, Cemorokandang, Kedungkandang, Malang City, Postal Code 65138. This research was conducted on the even semester of academic year 2016/2017. This research was conducted on 27 March-06 April 2017. The research procedure used: the planning stage of research, the stage of research implementation, the data analysis stage, and the final stage of the study. Subjects in this study were students of class VIII-B which amounted to thirty-one students. Furthermore, which will be the object of this research is the students' mathematical communication verbally as well as written by means the approach of SAVI (Somatic, Auditory, Visualization, Intellectually).

Data collection techniques used are observation and test. Observation is used to know the students' mathematical communication verbally as well as written, while the test is used as a support for observation of mathematical communication in writing. This test is given during the training phase in the learning process. The problem test is written test with the number of questions as much as two items related to the matter. The instrument used is an observation sheet to see students' mathematical communication verbally as well as written by means the approach of SAVI (Somatic, Auditory, 
Visualization, Intellectually) and the test sheet to see the students' mathematical communication in writing. Data analysis technique used are data analyzed every meeting and the whole of the meeting with reference to criteria of mathematical communication.

\section{RESULTS AND DISCUSSION}

The result of the mathematical communication of the students verbally obtained from observation during the learning process took place through SAVI approach (Somatic, Auditory, Visualization, Intellectually) with the material of polyhedron. The indicators used to determine students mathematical communications verbally are: (1) express an example of polyhedronin the neighborhood; (2) explain mathematics representation related to the material; (3) give questions and answers related to the material; (4) declare the situation or picture of a problem in mathematical model; (5) discuss the problem related to the material; (6) concludes the result of group discussion; and (7) summarize the related summary of the material that has been studied. The results of students mathematical communication analysis verbally by means the approach of SAVI (Somatic, Auditory, Visualization, Intellectually) reached good mastery level. Each aspect of mathematical communication has been done by students well.

The first verbally mathematical communication indicator is expressing an example of polyhedronin the neighborhood. Students have been able to name examples of objects around the beam-shaped like cupboard, pencil box, and tissue box. The SAVI element that appears in this indicator is auditory learning by listening and speaking. The second verbally mathematical communication indicator is explaining a mathematical representation related to the material. Students have been able to explain the characteristics of the cube that has 12 sides of the same length, 3 pairs of parallel sides and 8 equal angles. The SAVI elements that appears in this indicator are auditory, visual and intellectual learning by talking, listening, seeing and thinking. The third verbally mathematical communication indicator isgiving questions and answers related to the material. Students have an active role in questioning such as mentioning the types of prism. The SAVI elements that appears in this indicator are auditory, visual and intellectual learning by talking, listening, seeing and thinking. The fourth verbally mathematical communication indicator is declaring a situation of a problem into the mathematical model. Students have been able to explain a situation on matter into a mathematical model such as how to determine the base and the height of a trapezoid 
prism. The SAVI element that appears in this indicator are visual and intellectual learning by seeing and thinking. The fifth verbally mathematical communication indicator is discussing the problem related to the material. Students have been active in discussing and solving problems correctly and completely as discussed in solving the problem about the surface area of the beam. The SAVI elements that appears on this indicator are the auditor, visual and intellectual learning by talking, listening, seeing and thinking.

The sixth verbally mathematical communication indicator is concluding the result of group discussion. Students have been able to summarize the results of group discussions correctly and completely such as reading out the results of group discussions in front of his friends. The SAVI elements that appears in this indicator are somatic, auditory, visual and intellectual learning by moving, speaking, listening, seeing and thinking. The seventh verbally mathematical communication indicator is summarizing the related summary of the material that has been studied. Students can already deduce what has been learned at the meeting. The SAVI element that appears in this indicator are auditory and intellectual that is learning by talking, listening and thinking.

The result of the mathematical communication of the students in writing is obtained from the test sheet and observation sheet during the learning process through SAVI (Somatic, Auditory, Visualization, Intellectually) approach with the material of polyhedron. Indicators used to identify students' written mathematical communications are: (1) write the mathematical ideas that are presented at apperception; (2) write a mathematical representation of matter; (3) write the important points of the material; (4) write what is known in the problem into the mathematical model; (5) solve mathematical problems related to the material; and (6) write a summary related the material that has been learned.

The result of mathematical communication analysis of students in writing through SAVI (Somatic, Auditory, Visualization, Intellectually) approach reaches good mastery level. Each aspect of mathematical communication has been done by students well. The first written mathematical communication indicator is writing the mathematical ideas conveyed at apperception. Students have been able to write mathematical ideas such as the area of the base beam $=p \times l$, the area of the base of the triangle $=\frac{1}{2} \times a \times t$, the width of the diamond $=\frac{d_{1} \times d_{2}}{2}$, and the trapezoidal area $=\frac{1}{2} \times$ sum side parallel $\times t$. 
The SAVI elements that appears on this indicator are auditory, visual and intellectual learning by listening, seeing and thinking. The second written indicator of mathematical communication is writing a mathematical representation of matter. Students can already write a mathematical representation such as writing the characteristics and understanding of the cube by looking at the picture. The SAVI elements that appears in this indicator are visual and intellectual learning by seeing and thinking. The third written mathematical communication indicator is writing the important points of the material. Students have been able to write important points of material such as surface area of prism $=2 \times$ base area + circumference of base $\times$ height. The SAVI elements that appears in this indicator are auditory, visual and intellectual learning by listening, seeing and thinking.

The fourth written indicator of mathematical communication is writing what is known in the problem into the mathematical model. Students have been able to write what is known in the problem into mathematical models such as triangular sides length $=$ $6 \mathrm{~cm}$, base $=8 \mathrm{~cm}$, vertical side area $=24 \mathrm{~cm}^{2}, 32 \mathrm{~cm}^{2}$, and $40 \mathrm{~cm}^{2}$. The SAVI elements that appears in this indicator are visual and intellectual learning by observing and thinking. The fifth written indicator of mathematical communications is solving mathematical problems related to the material. Students have been able to solve math problems correctly where the surface area of pyramid in question number 1 is $120 \mathrm{~cm}^{2}$ and in question number 2 is $384 \mathrm{~cm}^{2}$ and complete with the conclusion. The SAVI elements that appear in this indicator are auditory, visual and intellectual learning by talking, listening, observing and thinking in solving problems. The sixth written mathematical communication indicator is writing a summary of the material that has been learned. Students can already write a summary of the material that has been studied such as understanding pyramid and surface area of pyramid. The SAVI element that appears in this indicator is intellectual learning by thinking.

Students' mathematical communication verbally through SAVI (Somatic, Auditory, Visualization, Intellectually) approach in a good category. This means that students have been able to express the example of polyhedron in the neighborhood, explain a mathematical representation related to the material, give questions and answers related to the material, declare the situation of the problem in the mathematical model, discussthe problem related to the problems, concludes the result of group discussion, and 
summarize the related summary of material that has been well studied. Student mathematical communication in writing through SAVI (Somatic, Auditory, Visualization, Intellectually) approach in a good category. This means students can write mathematical ideas that are presented at apperception, write a mathematical representation, write the important points of the material, write what is known in the problem into the mathematical model, solve the mathematical problems related to the material, and write a summary related the material well.

Based on research data of students' mathematical communication verballyas well as written by means approach of SAVI (Somatic, Auditory, Visualization, Intellectually) atclass VIII-B SMP Negeri 22 Malang is in good category. According to Haerudin (2013), SAVI approach provides greater opportunities for students in developing their mathematical communication verballyand written. Students who scored low in mathematical communication because less meet the indicators of mathematical communication well. While students who scored high in mathematical communication because already meet the mathematical communication indicators well. This is in line with Sulthani (2012) research that students at level 0 and level 1 (low level) use mathematics language inaccurately and provide improper solutions in working on problems or math problems does not even provide solutions and workmanship at all. While students at level 3 and level 4 (high level) have been able to use the language of mathematics very effective, accurate, provide the correct solution exposure and demonstrate appropriate strategies even if there is a small error in computation.

\section{CONCLUSION}

Based on the research results obtained, it can be concluded that:

a) Students mathematical communication verbally through SAVI (Somatic, Auditory, Visualization, Intellectually) approach in a good category. This means that students have been able to declare an example of polyhedronin the neighborhood, explain a mathematical representation related to the material, give questions and answers related to the material, declare the situation or picture of a problem in mathematical model, discuss a problem related to the material, concludethe resultofgroup discussion, and summarize the related summary of material that has been studied well. 
b) Students' mathematical communication in writing through SAVI (Somatic, Auditory, Visualization, Intellectually) approach in a good category. This means students can write the mathematical ideas, write a mathematical representation of the material, write the important points of the material, write what is known in the problem into the mathematical model, solve mathematical problems, and write a summary related the material that has been learned well.

\section{REFERENCES}

Ansari, B. I. (2009). Mathematical Communication Concepts and Applications. Banda Aceh: Pena.

Darkasyi, M., Johar, R., \& Ahmad, A. (2014). Improvement of Mathematical Communication Skills and Student Motivation with Learning of Students Quantum Learning Approach at SMP Negeri 5 Lhokseumawe, 21-34.

Elidia, N. (2012). Improve The Mathematical Communication Ability Of Junior High School Students Through Think-Talk-Write (TTW) Learning. Scientific journals Study Program of Mathematics STKIP Siliwangi Bandung. 1(2): 178-185.

Hamid, S. (2011). Metode Edutainment. Jogjakarta: DIVA Press.

Haerudin. (2013). The Influence of SAVI Approach to Communication Skill and Mathematical Reasoning and Junior High School Student Self-reliance. Scientific journals Study Program of Mathematics STKIP Siliwangi Bandung. 2(2): 183- 193.

Istiqomah, N. (2007). Efforts to Improve the Communication Skills of Mathematics Students of SD Negeri Sekaran 2 on Basic Material of KPK and Fraction by using KBK Learning is characterized by Utilization of Mentoring Equipment Tool. (Online),(http://digilib.unnes.ac.id/gsdl/collect/skripsi/archives/HASH01a1/01cb64 33. dir/doc),

Mayliana, E. \& Sofyan, H. (2013). Application of Accelerated Learning With Savi Approach to Drawing Clothing Competition. Journal of Vocational Education. 3(2): 14-28. National Council of Teachers of Mathematics. (2000). Principles and Standards for School Mathematics. (Online), (http: //www.nctm.org/standars/overview.html), diakses 10 November 2016.

Permendikbud. (2016). Regulation of the Minister of Education and Culture No. 20, 21, and 22, Year 2016, on Graduate Competency Standards, Content Standards and Standards Process Primary and Secondary Education.

Putra, H. D. (2011). Geometry Study with SAVI-Assisted SAVI Approach to Improve Mathematical Analogic Ability of Junior High School Students. Proceedings of the National Seminar on Mathematics Education STKIP Siliwangi Bandung. 1:1-11.

Sulthani, N. A. Z. (2012). Mathematical Communication Skills of Excellence Class Students and Students Regular Class X Class SMA Panjura Malang On Mathematical Logic Material. Online Journal State University of Malang. 1(1). 
Turmudi. (2008). The Foundation of Philosophy and Mathematics Learning Theory (Paradigm Eksploratif and Ivestigatif). Jakarta: Leuser Cita Pustaka. 